\title{
Professional Competence of Supervisory Staff of the National Police of Ukraine
}

\author{
Vadym Barko, Volodimyr Ostapovich, Iryna Koval, Vitalii Lunov, Alexander Kocharian, \\ Natalia Barinova, Liana Onufriieva
}

\begin{abstract}
Among the primary tasks of increasing effectiveness of the law enforcement activity the most important is establishment of the system will allow to the agencies and units of the National Police with supervisory staff who have necessary qualities for successful acquirement of the law enforcement profession, and further, to keep their efficiency, to increase reliability, to develop a professional potential. Thus the article deals with modern approaches to the comprehension of professional competence and competencies of managers of police units, reveals their essence and structure. It presents the main components of professional competence of a police manager planning and control, decisions making and responsibility, team work and motivating, stress tolerance, as well as marks psychological tools for studying the level and structure of professional competencies - structured interview, CV assessment, use of psycho-diagnostic methods etc. The material of the article will help to develop an integrated strategy of selection of supervisory staff of the National police within the framework of the concept of personnel policy, which will ensure the success of solving tactical tasks for the identification of professionally important qualities and evaluations of psychological suitability.
\end{abstract}

Keywords : National Police, professional competence, professional psychological selection, professionally important qualities, psychological suitability.

\section{INTRODUCTION}

According to the Law of Ukraine "On National Police", it is a central executive body which serves society through ensuring the protection of human rights and freedoms, combating crime, maintaining public security and order. The tasks of the police are to provide police services in the spheres of public security and order, protection of human rights and freedoms, interests of society and the state, crime prevention,

Revised Manuscript Received on November 15, 2019

* Correspondence Author

Vadym Barko, Candidate of Pedagogical Sciences (PhD), Senior Researcher, State Research Institute of the Ministry of Internal Affairs of Ukraine

Volodimyr Ostapovich, Candidate of Juridical Sciences (PhD), Chief of Laboratory, State Research Institute of the Ministry of Internal Affairs of Ukraine

Iryna Koval, MD, PhD. D.P., Docent, Professor Department of Medical Psychology, Psychosomatic Medicine and Psychotherapy, Bogomolets National Medical University, Ukraine

Vitalii Lunov *, PhD, Associate Professor, Bogomolets National Medical University, Ukraine, email: lunyov_vitaliy@ukr.net

Alexander Kocharian, Doctor of Psychological Sciences, Professor. V. N. Karazin Kharkiv National University, Head of the Department of Psychological Counseling and Psychotherapy, Ukraine.

Natalia Barinova, PhD., Department of Psychological Counseling and Psychotherapy, V.N. Karazin Kharkiv National University, Kharkiv, Ukraine

Liana Onufriieva, PhD., Professor (Associate), Kamianets-Podilskyi National Ivan Ohiienko University, Kamianets-Podilskyi, Ukraine render citizens relevant services. Police officers perform official tasks on the basis of the strict observance of the rule of law, human and civil rights (Zakon Ukrainy Pro Natsionalnu politsiiu, 2015). Official activities of police officers are traditionally considered as complex ones and characterized by a significant psychophysiological and physical impacts on employees, and the activity of police managers is especially difficult. Not all people are able to cope with managerial responsibilities; therefore, there is an important issue of studying potential and professional competence of police managers under their positions mobility and promotion. In the context of reforming of law-enforcement authorities of our state, special attention is paid to the study of professional-managerial competence of heads of police units; researchers believe that it influences successful activities of police units, the quality of managerial decisions and, for this reason, it is crucial to clarify its content and structure. Consequently, the purpose of the article is to cover the content and structure of the professional competence of the manager, as well as performance capabilities of some psychological tools for studying professional competence of executive staff of the National Police of Ukraine.

\section{THEORY}

Professional competence of a manager is traditionally understood as a generalized personal complex that includes his/her mastery of formed expertise. In turn, scholars refer required knowledge, skills and work methods of the chief as well as developed professionally important qualities and professional managerial experience, which ensures the effectiveness of his/her executive activities, to competencies (V. Barko, 2009). Thus, scholars differentiate concepts "competence" and "competency", and most of authors mark that competence is a scope of competencies realized in activities (V. Barko \& V. Ostapovych, 2017). At the same time, scholars emphasize that in the most general terms, a competency should be understood as the ability of a person to perform certain activities in accordance with the requirements, and competence determines a level of competency mastery (usually it's not one but several) (V. Barko \& V. Ostapovych, 2017).

Now, there are a lot of papers describing the structure and content of professional competence of experts in different spheres of professional activity. Thus, some scholars mark four components in the structure of expert's competence: special, social, personal and individual, describing them as types of professional competence (R. Cochraine, R. Tett \& L. Vandecreek, 2003). Indicators forming the competencies through their manifestations are also characterized (H. Chukhraieva, 2016). Other

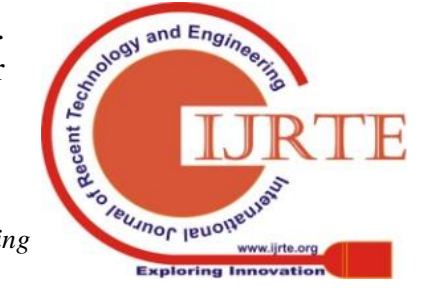




\section{Professional Competence of Supervisory Staff of the National Police of Ukraine}

scholars, on the basis of the provisions formulated in psychology, identified three main groups of competencies: competencies relating to the very employee as a personality and subject of life activity; competencies related to person's interaction with others; competencies related to person's activity and are manifested in all its types and forms (E. Klymov, 1995). We believe that the most logical and theoretically substantiated modeling of professional competence presents the structure of professional competence in two cases as follows: 1) functional-substantial - it is considered as a set of competencies related to the scope of activities, communication and behavior concerning a specific object of activity, communication, behavior; functional-substantial components of professional competence in this model are the following components: general professional (general scientific and research competencies); general branch (educational and specific competencies related to the training of experts in a particular sphere); special (pedagogical, managerial, recreational competencies); 2) psychological - it is a set of cognitive-intellectual and activity-behavioral components. Moreover, cognitive-intellectual factors include expertise, knowledge and skills, indicators of thinking; activity-behavioral indicators (experience of behavior, activity and communication) (R. Muchynskyi, 2004).

From our point of view, it is expedient to distinguish two basic competencies in the model of professional competence of any expert: 1) the professional competencies which include the requirements applicable to a head in accordance with the content and specific nature of professional managerial activities; 2) professional competencies covering professional-psychological characteristics of a person, that is, professional and individual-psychological qualities of a head ensuring the success of his/her professional managerial activities.

Conditionally, professional-psychological characteristics can be divided into personal and activity components as it is presented in figure 1 .

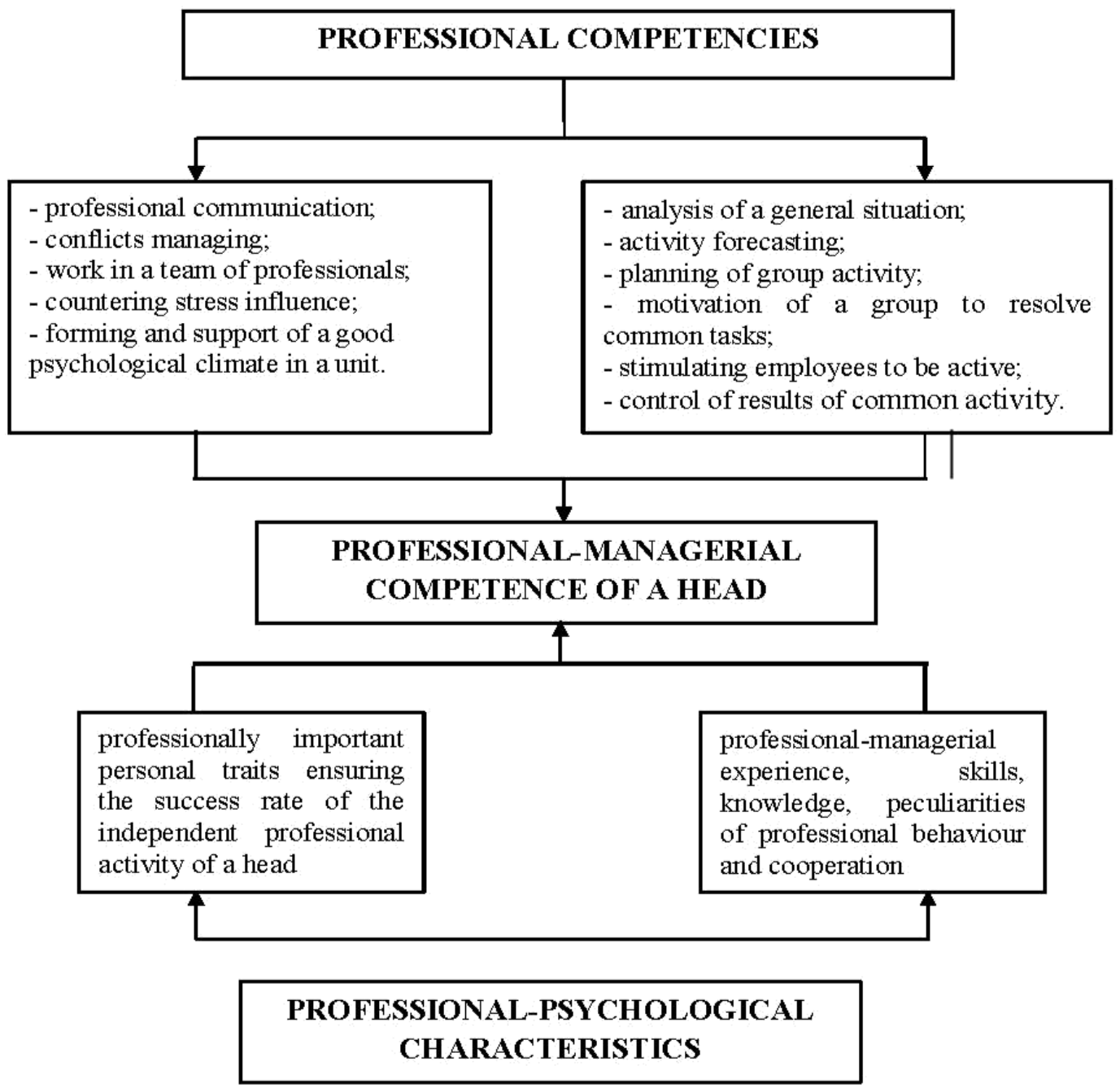

Fig. 1. General structural model of professional competence of a head

It is also expedient to mark two basic components in the structure of head's professional competence (in particular, head of a police unit) based on the above general model: professional competencies including professionally required knowledge (cognitive component) and professional-managerial abilities (functional and activity component) in accordance with the requirements applicable to the content and a specific nature of head's professional and managerial activities professional-psychological characteristics representing professionally important individual-psychological qualities of the head which ensure the success rate of his professional/her management activities. Professional-psychological characteristics can be conditionally divided into 

management competence of the head of a police unit are represented in figure 2 .

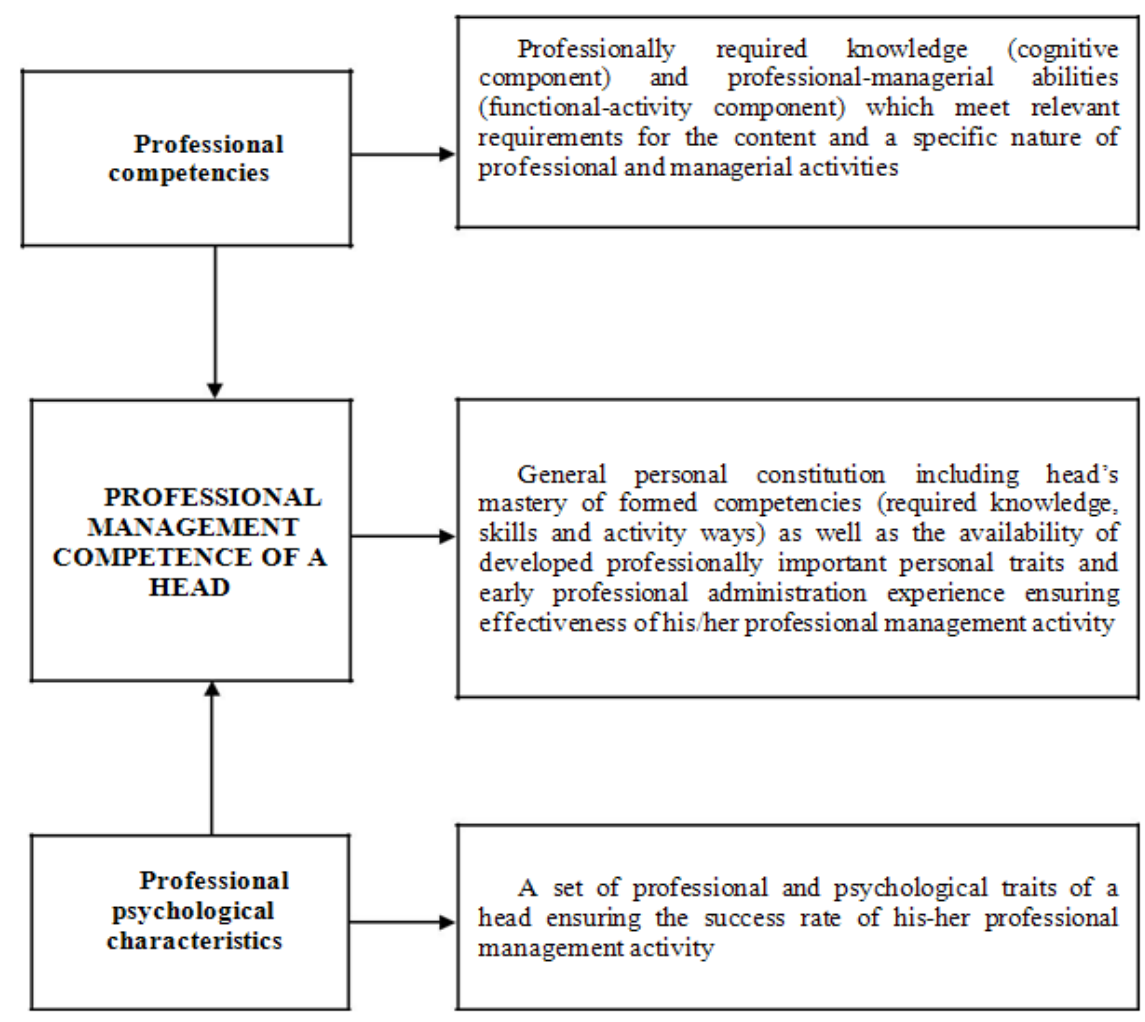

Fig. 2. Basic components of the structure of professional management competence of head

Taking into account the above, one can conclude that the model of professional managerial competence of the head of the police unit is a system of professional knowledge, skills and individual psychological qualities that collectively ensure the effectiveness of technologies of purposeful influence on the processes that take place in the head's organizational unit and create the necessary conditions for solving law enforcement tasks.

A cognitive component of the structure of professional managerial competence of the head is a set of knowledge which can be conditionally divided into two groups taking into account the scope of their application:
- specialized knowledge in management activity in the police: peculiarities of the organization of management process (including the content and specifics of the application of normative legal acts), the peculiarities of the organization of the management process in the professional activity of the head, the functional content of the head's management activity, etc.;

- knowledge of the psychological foundations of management activity of the head: motivational theories, socio-psychological peculiarities of the functioning of the team, leadership styles, etc.

The structure of cognitive component of professional management competence of the head is represented in figure 3.

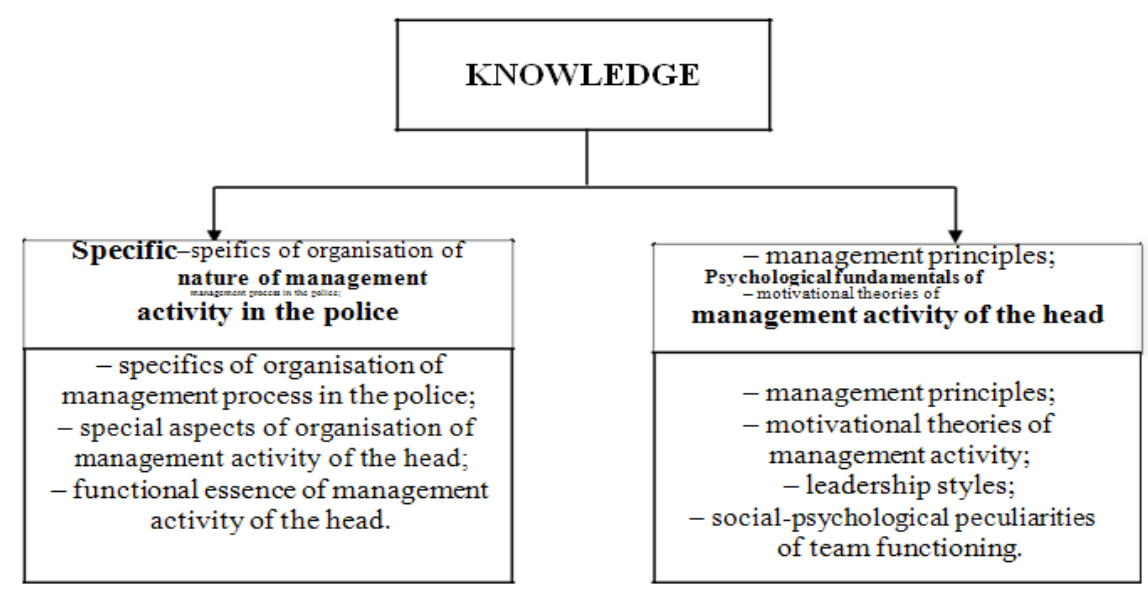

Fig. 3. The structure of the cognitive component of professional management competence of head 


\section{Professional Competence of Supervisory Staff of the National Police of Ukraine}

Functional-activity component is abilities oriented to head's skill to exercise managerial functions in the professional activity effectively. Compared to cognitive component, the functional-activity one is formed on the basis of the introduction of theoretical models into professional activity. It is obvious that it is not enough to have knowledge of the motivational theories for the formation of the ability to motivate subordinates effectively, it is important to be able to use it in management activities.

Based on the classification of management functions, traditional for theory of management, the structure of functional-activity component of head's professional competence includes the following skills: planning of group and own activities; organization of joint activities of employees; motivation of the team for solving professional tasks; stimulation of subordinates to productive activities; control of the results of the joint activities of police officers (figure 4).

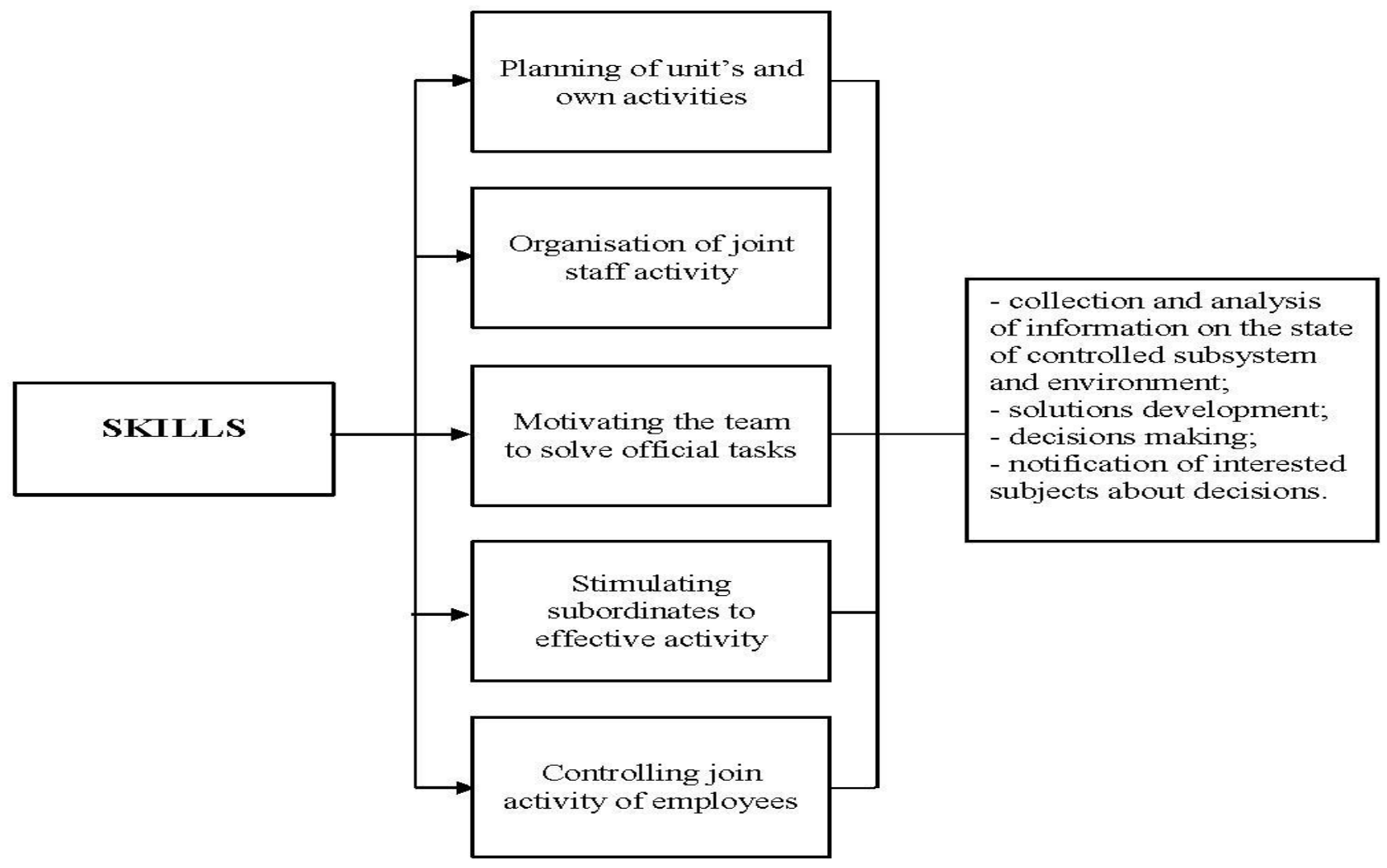

Fig. 4. The structure of functional-activity component of professional head competence

The above skills allow head to exercise important functions for making managerial decision in the context of collection and analysis of information on the state of the controlled subsystem, the development and decisions making, bring them to the notice of the objects of management.

Thus, the model of professional management competence of the head of the police unit is in the form of a system of professional knowledge and skills, which ensure the effectiveness of the application of technologies of purposeful influence on the processes taking place in the formal organizational unit subordinated to the head create the necessary conditions for the solution of the tasks of the police unit.

\section{METHODS}

To solve the tasks we have developed a research program, the implementation of which involves the use of a set of theoretical methods: analysis and synthesis of scientific psychological literature, content analysis of the legislative framework and synthesis of the information. In order to study the psychological characteristics of the police officers' work activities and specialists' professionally important qualities, a pilot research was conducted during 2018. 120 police managers from 10 regions of Ukraine took part in it; 80 policemen were men, 40 - women. The age of the surveyed ranged from 26 to 40 years, the special ranks of the respondents - police majors and colonels. The work experience of respondents in the police was from 2 to 15 years. The methods of observation and the included monitoring of the police officers' activities, timekeeping of official actions, sound- and video- recordings, questioning, psychological diagnostics, testing, interviewing, expert assessment, mathematical statistics were used in the research process. For the research, sufficiently reliable and valid psychodiagnostic methods were chosen that allow the diagnosis of personality traits, namely: 1) «Individual typological questionnaire», ITQ (L. Sobchik, Ukrainian adaptation by V. Barko), contains eight scales (1 extroversion, 2 - spontaneity, 3 - aggressiveness, 4 - rigidity, 5 - introversion, 6 - sensitivity 7 - anxiety, 8 - lability); 2) «Standardized method of personality research», SMPR (L. Sobchik), includes ten main scales (1 - overcontrol, 2 depression, demonstrativeness, 4 impulsivity, 5 - femininity, 6 - 
rigidity, 7 - anxiety, 8 - individualism, 9 - optimism, 0 social introversion); 3) «Big Five personality traits», also known as the five-factor model, FFM (O. John, L. Nauman and S. Soto, adapted by V. Barko) presented by five scales (1 - extroversion, 2 - agreeableness, 3 - conscientiousness, 4 - neuroticism, 5 - openness to experience); 4) «Interpersonal Diagnosis of Personality», IDP (T. Leary), differentiates eight types of interpersonal relationships $(1$ - power-leading, 2 independent-dominant, 3 - straight-aggressive, 4 incredulous-skeptical, 5 - obediently-modest, 6 dependent-compliant, $7-$ conventional 8 responsible-generous).

Study of professional-psychological characteristics of a manager. In order to study professional-psychological characteristics of a head, the psychological tools for conducting a competition for senior positions in the police are additionally used. The research showed that in order to evaluate the intellectual components of managerial skills it is expedient to use the following psychological tools.

Intelligent Structure Test, 2000R, made by R. Amthauer. The test is used to assess the level of the intellectual development of people aged 13 to 60 years with the aim of differential candidates' selection for different types of professional orientation and professional selection. The test diagnoses the verbal and nonverbal components of intelligence, in particular verbal, calculating-mathematical, spatial, and mnemonic; it is based on the idea of Ch. Spearman on the presence of general intelligence factor $(G)$ and a number of specific factors. The test presented by $\mathrm{R}$. Amthauer in 1953 (revised in 1973) and it is still one of the most valid and reliable methods for studying the level and structure of intellect. The test consists of 9 sub-tests.

In total, R. Amthauer test has 176 tasks for interviewees. The test duration is 90 minutes. When calculating "raw" grades (except for the 4th subtest), the correct response is assessed at 1 point. Sum of primary scores for all subtasks is the general estimate of intelligence level. The profile is analyzed separately. R. Amthauer suggests that if an interviewee obtains the highest results in the first four subtests, he/she has developed "theoretical abilities". In the case when the results are better for the last five subtests "practical abilities" prevail. According to R. Amthauer, correlations with academic success - 0,46; with expert estimates of intelligence level -0.62 .

Guildford Unusual Using Test (adaptation of V. Barko. V. Panok \& S. Lazarevsky) allows assessing the level of human creativity based on parameters of mental speed, flexibility and originality of the verbal creative process. Studies confirmed the high reliability of the test $(0,73-0,79)$ and validity on the criteria for creative activity, although the indicators of the latter vary depending on the type of creative activity.

Divergent thinking test "Unusual thinking" is developed on the basis of J. Guildford ideas and designed for people aged 12 years. Test duration is 6 minutes. The task of the test is to make up as many as possible different (including unusual) ways for using ordinary object, and write them down. After the test, the results are evaluated using a key that allows determining the level of speed, flexibility and originality of the divergent thinking of the respondents by categories, subcategories and specificsBar-On Emotional Quotient Inventory. It was developed by a clinical psychologist $\mathrm{R}$. Bar-On in 1996. There is EQ coefficient of emotional intelligence (EI) according to IQ scale. In opinion of R.
Bar-On, EI is a set of non-cognitive knowledge and skills which affect the ability to cope with the requirements and pressure of society successfully.

The inventory assesses five main components of EI: intrapersonal (self-esteem), interpersonal (compassion, responsibility), adaptability (the ability to adjust own emotions to changing conditions), self-management (stress tolerance), and general mood (optimism level).

\section{RESULTS AND DISCUSSION}

Psychological studying of professional competence of a police manager. The study of the experience of developed foreign countries of the world shows that the procedure of investigation of the professional competence of police managers is a rather complex process which involves a number of socio-psychological methods, including CV study and job talk with a candidate (interview) (M. Meskon, M. Albert \& F. Khedory, 1992).

CV study is usually performed in the express mode according to the following parameters: the last place of employment, education, age, knowledge of a foreign language, specialized computer programs, motives of professional activity, etc. CVs selected due to a quick review are studied in detail. Attention is drawn to the quality of basic and additional education, to the level of organizations where the candidate has worked or is working, to his achievements in the official activities. After a preliminary analysis of a CV, a candidate has a job talk (interview) during which data on his communicative abilities, the level of general education can be obtained. Such kind of scheduled job talk is called structured interview. The technology of structured interviews is widely used in the process of assessing staff and police heads, and this assessment is based on competency framework. As a rule, an interview is conducted when deciding on the recommendation of police officers for managerial posts of different levels. Moreover, the very structured interview is the main instrument for competency assessment. For this reason, it is essential to draw attention to studying professional suitability of the senior staff of the National Police of Ukraine.

We are going to consider the psychological methods and tools which are used in the process of studying police officers through structured job talk (interviews). During an interview, a police officer answers a variety of questions in a free format, which mainly relate to the experience in solving (overcoming) one or another official and life situations (problems). Based on the analysis of the content of his answers, a psychologist or HR manager, using a specific method, determines the availability and degree of development of one or other competencies essential for the effective performance of official activities in the person. In the case of proper application, the method of competency assessment is quite accurate and predictably valuable.

The technique of interviewing has many options depending on the purposes it is focused on. Its basis is to get an idea of policeman's competencies which include integral characteristics that determine his successful official behavior and personal qualities combining abilities, knowledge and skills. It is competencies which determine person's working efficiency in a particular position. 


\section{Professional Competence of Supervisory Staff of the National Police of Ukraine}

Experience shows that job talks and interviews with direct questions ("What can you do?", "What kind of work do you like most?", "What your qualities do you consider most important?" etc.) are often ineffective as people are not always able to present objective information. During interview many respondents seek to provide socially or contextually desired answers "decorating" the real state of affairs.

Well-formed interview is based on the suggestion that the most reliable basis for the findings is the information about person's real actions which he practiced in different conditions and situations but not his thoughts and suggestions about the qualities causing these actions. It is evident that dishonest employee can provide unreliable information about the real facts of his life (but a lie about events that really took place can be easily detected by means of psychophysiological methods for information fidelity assessment). In general, it should be noted that interviewing to assess competencies is a complex and time-consuming process that requires an interviewer with appropriate professional training and advanced communication skills. In addition, the very preparation of this process and the preliminary construction of competency framework is also a complicated matter.

The main objective of an interview for competency assessment, or behavioral interview, is to find out detailed information on how an employee works out official functions in different situations. During this interview, a police officer does not evaluate his actions but just describes his behavior, feelings and actions (relating to the competencies being studied) in different circumstances. Compared to common job talks, such an interview can be conducted by several interviewers, whose tasks, roles and functions are carefully planned in advance that makes the preparation of the interviews more complicated.

An interview aimed at identifying competencies consists of two stages: a) an introductory one where the necessary contact between the interlocutors is established and the general information about the employee and his activities is found; $b$ ) the main where questions of competencies are raised.

All questions are carefully planned and processed in advance in content that reflects their connection with the competencies that are being studied. It also reflects on the total number of questions and the sequence of their presentation. In addition, temporal factor also plays important role. As practice shows, getting detailed answer to a well-formulated question is from 5 to 10 minutes. The interview is thoroughly documented in a mandatory manner using any means - from recording in the notebook to high-quality audio and video recording.

The variability of situations of police official activities creates a large number of different competencies necessary for success of these types of activities. In addition, it is necessary to use professional set of critical competencies, which are called competency frameworks in personnel practice, for every type. It is clear that there are a large number of such frameworks. Therefore, in each specific case, or more specifically in the case of competency assessing of each particular employee, it must concern a specific framework of competencies according to the post and relevant competencies that form the content of the framework.

As an example, we consider the post of head of the police unit for which competency framework for successful activity has been developed. As researches showed, it is important for the head of police unit to have four key competencies (in fact, depending on the complexity of the work and the conditions in which it is carried out, there may be more): planning and control; decision making and responsibility; team work and personnel motivation; stress tolerance. To assess the availability and degree of development of the competencies of the candidate for the position of head of the police unit, the following questions can be prepared for the interview.

Introductory stage. Describe the activities in your post", "What tasks does your post solve?", "What specific functions do you perform?"; 2) "What do you do best in work?", "What do you think, due to which skills and abilities do you succeed in it?", "Where don't you always succeed?", "What are the reasons for this?"; 3) "What specific difficulties do you have in your work?", "Give examples how you overcome these difficulties".

\section{Main stage.}

1. "Planning and control". 1) "Tell us, how do you manage large volumes of work?", "What do you usually start work with?", "What do you do to ensure timeliness and adequate level in carrying out tasks?", "What does usually impede you to perform your work?"; 2) "Have you had situations when you had to perform rush work within short timeframes?

Give an example", "What did you help to cope with this work?", "What conclusions did you do for yourself?"; 3) "Describe a specific recent case where you have not been able to do work in time", "What have been the reasons?", "What is your personal responsibility for breaking the deadlines?", "What specific actions have you made in order to overcome the situation at hand?"; 4) "Even the best employees (heads) sometimes miss the essential elements in planning. Did you have some mistakes in planning? Give an example.", "What were the consequences?", "How did you rectify the situation and what was the result?".

"Making decisions and responsibility". 1) "What sort of decision do you usually have to take?", "What do you rely on when deciding?", "What difficulties do you face when deciding?" Give examples"; 2) "What decisions are easiest for you? Why?", "And what decisions are the most difficult for you? Why?", "Did you have to take difficult decisions? Give an example"; 3) "What is necessary to make correct decisions?", "Give examples of correct decisions from your experience", "And give examples of wrong decisions", "What were their consequences?"; 4) "Give an example when you had to act absolutely independently in an unusual situation", "What decisions did you have to take then?", "What was the result?"; 5) "Give an example from a recent past when you have did beyond the call of duty", "Why have you done it?", "How did your seniors and colleagues take your initiative?".

3. "Team work and motivating". 1) "How do you assess the psychological climate and atmosphere in your team in general?", 2) "Do you being asked for help, advice or support of a colleague? How often?", "Why do they do it? Give examples", "Do you provide them with real help?"; 3) "What conflict situations did you face in a team?", "How did resolve these conflicts?", "Did you actively participate in it?"; 4) How do you act if you are not satisfied with work of your colleague or subordinate? Give an example"; 5) "What is an ideal leader in your opinion?", "What methods do you use to motivate your colleagues and employees? Give an example".

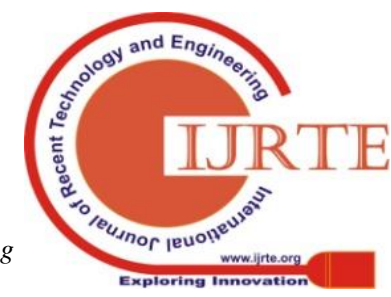


4. "Stress tolerance". 1) "Did you had any crisis situations in the past where you had to make decisions and act?", "What was the cause of the crisis?", "What did you do to overcome it?", "What feelings did you experience during this period?"; 2) "Did you have serious failures? Give an example, tell me what happened, and how did you react to it?", "How did surrounding people treat you during this period?"; 3) "Describe an official situation which caused your negative reaction", "How did you resolve this situation?", "How did your colleagues react to it?"; 4) "Did you have to show persistence and patience to overcome the undesirable situation? Give an example", "What was the reason for the resistance to solving the situation?", "How did you manage to overcome it and what was the result?; 5) "Give an example of a situation when you had to maintain your own position on a particular issue. How did you feel then?", "What arguments and techniques did you use?".

On the basis of analogy, one can elaborate questions towards any other competencies essential to police officers, for example, "influence on subordinates", "fence-mending", "interpersonal understanding", "analytical thinking", "innovation and creativity" etc. Competency-based interview is carried out observing the requirement of "linguistic domination" of interviewee, that is, questions and comments of the interviewer should be no more than $15-20 \%$ of the time. The rest of the time should be taken for the employee's answers, his narration and explanations Analysis of the information obtained during the structured interview should be implemented by an expert group. The scope and depth of the analysis depend on the tasks. In the process of analysis, initially, it is marked clear "behavioral examples" in the statements of the person under review, then their differentiation with respect to "positive" and "negative" is implemented. The positive and negative examples are classified according to the competencies under study and then they are estimated quantitatively (usually according to five-point grading scale) in relation to one or another competency. Ultimately, the data is summarized and the final conclusions are formulated.

It is important to turn attention to the main principles for the construction of structured interview taking into account analysis of non-verbal features. Numerous researches show that there are obvious differences between the effective and ineffective way of conducting a job talk in the form of a structured interview (if the quality of obtained information is a basis) caused by behavioral tactics of the interviewer. The difference lies in the fact that a well-acting interviewer puts predominantly wide-range questions stimulating an interviewee to talk most of the interview time. In the case of an improperly organized interview, the interviewer predominantly speaks and puts forward mostly direct, narrow-minded and quite often guiding questions.

It is established that during an unprofessional structured interview, there are three main types of common mistakes: a) the interviewer often interrupts the interlocutor in the process of informing him without the need; b) the respondent is offered extremely large number of narrow-minded and guiding questions (narrow-minded, specific questions are less valuable in terms of obtaining information than broad-based ones, especially when they are raised too often since they cause less detailed answers); c) the sequence of questions is often thought-out in advance, it does not take into account the state and peculiarities of the thinking processes of the respondent. There are often awkward and unexpected questions impeding the normal performance of memory and information retrieval.

A kind of interview called "cognitive interview" is conducted using the following principles and techniques:

1) similarity of the situation of the real event and the interview. Human memory is improved when in the process of interviewing the general psychological environment is approximate to the situation that took place during this real event. Therefore, the interviewer should try to restore all possible external attributes of the event (including the situation, weather conditions, emotional experiences, and concomitant thoughts) in memory of the interlocutor;

2) focused nature of information reproduction. Reproduction of memorial content, like any mental activity, requires some concentration of effort. Therefore, the interviewer should continuously help the respondent focus his efforts on recollecting the relevant information. Any factors that may distract attention and interfere with this process (external noise, frequent interruptions, etc.), impair the memory performance towards information retrieval;

3) extensity of reproduction. In general, the more attempts are made by the respondent to reproduce a specific episode the more substantial information he reproduces. Therefore, it must be constantly encouraged to make as many attempts as possible to recall a certain event. Due to failed attempt many interviewees give up recalling, thus, it is important that the interviewer constantly stimulates attempts to recall the event, even if the interviewer states that he doesn't remember anything;

4) adjustment of questions to the interlocutor. Successful reproduction of some details from memory partly depends on the extent to which the content of the questions and the form in which they are presented correspond to the specific memory characteristic of a particular person. Therefore, it is important that the interviewer adjusts his questions to the interviewee as much as possible. Any unified method of questioning consolidated for different people will never be an effective stimulant for their memory, although it can formally simplify conversation procedure. Flexible interview methodology in the process of which the style and focus of interrogation vary in accordance with the psychophysiological features of a particular person is more effective.

It is expedient to ask the interviewee to express the essence of facts and events of interviewer interest in free form but, before, he should be provided with the following instructions: 1) reproduction of circumstances:

2) "Try to reproduce the environment surrounding the event of our interests in memory. Describe the premises, illumination, weather conditions, smells, objects and people in the vicinity. Remember your feelings and emotional experience. In the process of narration, try to cast mind back to the scene"; details presentation: "Sometimes people do not give all information of interest because they do not consider it to be important. Please do not try to sort information by relevance independently. Do not miss any detail. Describe all details, even the least important in your opinion"; 3) order change: "It is generally believed that the chronological sequence of the presentation is most convenient. However, try to tell everything in a different order. For example, start with

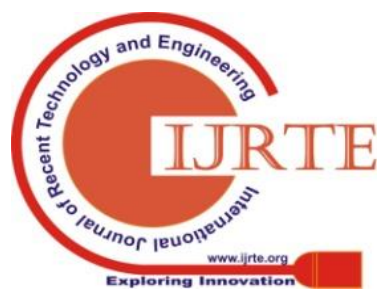




\section{Professional Competence of Supervisory Staff of the National Police of Ukraine}

what you think was the most striking and most important, and move in the story from that point through time back and forth"; 4) perspective change: "Try to state a situation of our interest from different standpoints. Imagine yourself in shoes of other participants and try to reproduce it again as they could see and hear all of those things".

Most researchers agree that the more accurately spatial-temporal context of events is reproduced in the process of interviewing, the more accurate and fuller the memories are. The imagine transference of a person in the described situation improves information recollection.

It stands to mention that during the conversation it can be used a number of specific questions, which after completing the free description, will help to improve the recall and specification of individual elements of the communicated information. The areas covered by these issues include as follows: a) description of physical characteristics ("Try to remember, does the person you describe remind someone? If so, think and say why". "Can you mark something unusual in his/her appearance?); b) names ("If you cannot remember the name, try to reproduce its first letter at least. Then try to remember the number of letters or vowels in that name"); c) numbers ("Was the number large or small?", "What was an approximate number of digits in it?"); d) speech peculiarities ("Remember, was the voice similar to someone else? If it was, think and say why", "Was anything unusual in the voice?"); e) content of conversations ("Remember your reaction to interlocutor's words. How did present company react to them?", "Was anything unusual in words?").

\section{CONCLUSIONS}

Researches showed that the use of the above psychological tools and methods for studying the professional competence of a police officer increases the quality and quantity of useful information obtained from a frank interlocutor. At the same time, under such conditions, the quality of information presented by an insincere employee is greatly declined and accompanied by a significant number of non-verbal features that allow identifying the statements as false with confidence. Thus, the essence of the above methods using for attention activation and stimulating the memory of a person in the process of studying the components of professional competence (in particular, in the form of a structured interview) lies in the differential influence on the speech-mental processes of the interlocutor. They contribute to improving and facilitating the recollection of the necessary information of a sincere person and intensify the complications associated with the presentation of a detailed "legend" and lead to non-verbal psycho-physiological features of the insincerity of a play actor. For this reason, the use of psychological tools for verifying professional competence and ability of a police manager to carry out the activity in the context of running competition for a senior position of a police employee is an important focus in improving the system of executive staff recruitment for law enforcement agencies of the state.

\section{REFERENCES}

1. Barko, V. I. (2009). Robocha knyha kerivnyka orhanu vnutrishnikh sprav (psykholoho-pedahohichnyi aspekt) : navch. posib. / V. I. Barko,
V. I. Zelenyi, Yu. B. Irkhin. - Vinnytsia : Knyha-Veha ; Vinnyts. obl druk.,- $129 \mathrm{~s}$.

2. Barko, V. I., Ostapovych, V. P. (2017) Psykholohichni mozhlyvosti vykorystannia strukturovanoho interviu $\mathrm{z}$ metoiu vyvchennia kerivnoho personalu Natsionalnoi politsii Ukrainy // Nauka i pravookhorona. 2. $-226 \mathrm{c}$.

3. Barko, V. I., Ostapovych, V. P., 2017. Strukturovana spivbesida yak zasib vyznachennia profprydatnosti kerivnoho personalu NPU. Pravo i bezpeka, 65(2), 119-125.

4. Cochraine, R. E., Tett, R., Vandecreek, L., 2003. Psychological Testing and the Selection of Police Officers: A National Survey. Criminal Justice and Behavior, 30(5), 511-537. Available at: http://dx.doi.org/10.1177/0093854803257241

5. Chukhraieva, H. V. (2016). Teoretychni ta praktychni aspekty profesiinoho psykhofiziolohichnoho vidboru pratsivnykiv politsii. Pravo i bezpeka, 60(1), 171-176.

6. Klymov, E.A. (1995) .Obraz myra v raznotypnыkh professyiakh. M.: Nauka. $-26 \mathrm{~s}$.

7. Muchynskyi, R. (2004). Psykholohyia, professyia, karera Muchynsky. Sankt-Peterburh: Pyter. $520 \mathrm{~s}$.

8. Meskon, M., Albert M., Khedory F. (1992). Osnovy menedzhementa: per. S . anhl. M: Delo. $462 \mathrm{~s}$.

9. Soshnykov, A. (2009). Otsenka personala : psykholohycheskye y psykhofyzyolohycheskye metody / A. Soshnykov, A. Pelenytsyn. - M. Eksmo,. $-110 \mathrm{~s}$

\section{AUTHORS PROFILE}

Vadym Barko, Candidate of Pedagogical Sciences (PhD), Senior Researcher, State Research Institute of the Ministry of Internal Affairs of Ukraine

Volodimyr Ostapovich, Candidate of Juridical Sciences (PhD), Chief of Laboratory, State Research Institute of the Ministry of Internal Affairs of Ukraine

Iryna Koval, MD, PhD. D.P., Docent, Professor Department of Medical Psychology, Psychosomatic Medicine and Psychotherapy, Bogomolets National Medical University, Ukraine

Vitalii Lunov *, PhD, Associate Professor, Bogomolets National Medical University, Ukraine, email: lunyov_vitaliy@ukr.net

Alexander Kocharian, Doctor of Psychological Sciences, Professor. V. N. Karazin Kharkiv National University, Head of the Department of Psychological Counseling and Psychotherapy, Ukraine.

Natalia Barinova, PhD., Department of Psychological Counseling and Psychotherapy, V.N. Karazin Kharkiv National University, Kharkiv, Ukraine

Liana Onufriieva, PhD., Professor (Associate), Kamianets-Podilskyi National Ivan Ohiienko University, Kamianets-Podilskyi, Ukraine 